\title{
THE PHYSICO-CHEMICAL PROPERTIES OF 2-METHOXYPHENOXYACETATES OF MN(II), CO(II), NI(II) AND CU(II)
}

\author{
W. Ferenc ${ }^{1 *}$, M. Bernat ${ }^{1}$ and J. Sarzyński ${ }^{2}$ \\ ${ }^{\prime}$ Faculty of Chemistry, Maria Curie-Sklodowska University, 20-031 Lublin, Poland \\ ${ }^{2}$ Faculty of Physics, Maria Curie-Sklodowska University, 20-031 Lublin, Poland \\ "Author for correspondence: e-mail: wetafer@poczta.umcs.lublin.pl
}

\begin{abstract}
The complexes of 2-methoxyhenoxyacetates of $\mathrm{Mn}(\mathrm{II}), \mathrm{Co}(\mathrm{II}), \mathrm{Ni}(\mathrm{II})$ and $\mathrm{Cu}(\mathrm{II})$ with the general formula: $\mathrm{M}\left(\mathrm{C}_{9} \mathrm{H}_{9} \mathrm{O}_{4}\right)_{3} \cdot 4 \mathrm{H}_{2} \mathrm{O}$, where $\mathrm{M}(\mathrm{II})=\mathrm{Mn}, \mathrm{Co}, \mathrm{Ni}$ and $\mathrm{Cu}$ have been synthesized and characterized by elemental analysis, IR spectroscopy, magnetic and thermogravimetric studies and also X-ray diffraction measurements. The complexes have colours typical for $\mathrm{M}(\mathrm{II})$ ions $(\mathrm{Mn}(\mathrm{II})$ - a pale pink, Co(II) - pink, Ni(II) - green, and $\mathrm{Cu}(\mathrm{II})$ - blue). The carboxylate group binds as monodentate and bidentate ligands. On heating to $1273 \mathrm{~K}$ in air the complexes decompose in the same way. At first, they dehydrate in one step to anhydrous salts, that next decompose to the oxides of respective metals with the intermediate formation of the oxycarbonates. Their solubility in water at $293 \mathrm{~K}$ is of the order of $10^{-5} \mathrm{~mol} \cdot \mathrm{dm}^{-3}$. The magnetic moments of analysed complexes were determined in the range of $76-303 \mathrm{~K}$. The results reveal them to be high-spin complexes of weak ligand fields.
\end{abstract}

Keywords: 2-methoxyphenoxyacetates, thermal stability, magnetic properties of $\mathrm{Mn}(\mathrm{II}), \mathrm{Co}(\mathrm{II}), \mathrm{Ni}(\mathrm{II})$, $\mathrm{Cu}(\mathrm{II})$.

\section{Introduction}

The carboxylates play an important role in inorganic and bioinorganic chemistry. Many metal cations in a great number of various biological processes are a component of several vitamins and drugs [1-3]. The carboxylates of $d-$ and $4 f-$ ion elements may be used as electric materials in the modern branches of techniques and technology or they may have applications as precursors in superconducting ceramic and magnetic field productions.

These kind of compounds are often used as catalysts, pigments, solvents, food preservatives and plastics productions.

From the survey of literature it follows that metal carboxylates may be applied for the produc- tions of high degree purity of metal oxides and polycarboxylic acids are often used for supramolecular compound synthesis, which in many cases, form with metal ions the molecular polymers containing in their structures, pores and channels owning to them they appear catalytic and adsorption properties. Therefore they may be used for the adsorption of inorganic gases such as: argon, nitrogen and hydrocarbons or small molecules of another inorganic compounds. Polycarboxylic acid may also form the molecules with two- and three - dimentional structures, yielding special magnetic and luminescence properties which let them be used in optical and electronic industries $[1,4,5]$.

2-Methoxyphenoxyacetic acid is a greywhite solid hardly soluble in water. A literature 
survey indicates that its compounds with various cations have been relatively seldom studied. The complex of $\mathrm{Cu}$ (II) with 2-methoxyphenoxyacetic acid was synthesized and its structure determined [6].

As a continuation of our studies on carboxylates we decided to synthesize 2-methoxyphenoxyacetates with $\mathrm{Mn}(\mathrm{II}), \mathrm{Co}(\mathrm{II}), \mathrm{Ni}(\mathrm{II})$ and $\mathrm{Cu}$ (II) and to study some of their properties not to be investigated so far, such as magnetic properties in the range of $77-303 \mathrm{~K}$ thermal stability in air at $293-1273 \mathrm{~K}$, solubility in water at $293 \mathrm{~K}$ and to record their FTIR spectra.

Thermal stability investigations give informations about the dehydratation process and the ways of decompositions, and the magnetic susceptibility measurements let study the kinds of the way of coordination of the central ions and ligands. The determination of the solubility is valuable because it informs about the practical use of acid for separation of transition metal ions by extraction or ion-exchange chromatographic methods.

\section{Experimental}

The 2-methoxyphenoxyacetates of $\mathrm{Mn}(\mathrm{II})$, $\mathrm{Co}(\mathrm{II}), \mathrm{Ni}(\mathrm{II})$ and $\mathrm{Cu}$ (II) were prepared by the addition of the equivalent quantities of $0,1 \mathrm{~mol} \cdot \mathrm{dm}^{-3}$ ammonium 2-metoxyphenoxyacetate $(\mathrm{pH} \approx 5)$ to a hot solutions containing the $0,1 \mathrm{~mol} \cdot \mathrm{dm}^{-3} \mathrm{Mn}(\mathrm{II})$, $\mathrm{Co}(\mathrm{II}), \mathrm{Ni}(\mathrm{II})$ and $\mathrm{Cu}(\mathrm{II})$ chlorides and crystallizing at $293 \mathrm{~K}$. The solid formed were filtered off, washed with hot water and methanol to remove ammonium ions and dried at $303 \mathrm{~K}$ to a constant mass.

The contents of carbon and hydrogen in the complexes and in the intermediate and final products obtained from their thermal decompositions determined by elemental analysis using a $\mathrm{CHN}$ 2500 Perkin-Elmer analyzer. The contents of $\mathrm{M}^{2+}$ metals were established by XRF method using spectrometer of X-ray fluorescence with energy dispersion EDXRF-1510 (CANBERRA firm).

Table 1. Elemental analysis data of $\mathrm{Mn}(\mathrm{II}), \mathrm{Co}(\mathrm{II}), \mathrm{Ni}(\mathrm{II})$ and $\mathrm{Cu}(\mathrm{II})$ 2-methoxyphenoxyacetates and their solubility in water at $293 \mathrm{~K}$

\begin{tabular}{cccccccc}
\hline $\begin{array}{c}\text { Complex } \\
\mathrm{L}^{-}=\mathrm{C}_{9} \mathrm{H}_{9} \mathrm{O}_{4}\end{array}$ & calcd & found & calcd & found & calcd & found & $\mathrm{mol}^{\mathrm{H} / \%} \mathrm{dm}^{3}$ \\
\hline $\mathrm{MnL}_{2} \cdot 4 \mathrm{H}_{2} \mathrm{O}$ & 5.32 & 5.14 & 44.18 & 44.11 & 11.23 & 11.20 & $2,61 \cdot 10^{-5}$ \\
$\mathrm{CoL}_{2} \cdot 4 \mathrm{H}_{2} \mathrm{O}$ & 5.27 & 5.11 & 43.82 & 43.76 & 12.76 & 12.70 & $9,28 \cdot 10^{-5}$ \\
$\mathrm{NiL}_{2} \cdot 4 \mathrm{H}_{2} \mathrm{O}$ & 5.28 & 5.04 & 43.84 & 43.04 & 11.90 & 11.70 & $1,50 \cdot 10^{-5}$ \\
$\mathrm{CuL}_{2} \cdot 4 \mathrm{H}_{2} \mathrm{O}$ & 5.23 & 5.27 & 43.42 & 43.58 & 12.76 & 12.70 & $5,11 \cdot 10^{-5}$ \\
\hline
\end{tabular}

The FTIR and FIR spectra of complexes were recorded over the ranges of $4000-400 \mathrm{~cm}^{-1}$ and $600-100 \mathrm{~cm}^{-1}$, respectively, using M-80 and Perkin-Elmer 180 spectrometers. Samples for IR spectra measurements were prepared as $\mathrm{KBr}$ discs. FIR spectra were obtained in Nujol mulls sandwiched between polyethylene plates (Table 2). The FTIR spectra of the intermediate and final products obtained from the complex thermal decompositions were also registered. 
Table 2. Wavenumbers $\left(\mathrm{cm}^{-1}\right)$ of $\mathrm{COO}^{-}$bands in the analysed complexes of $\mathrm{Mn}(\mathrm{II}), \mathrm{Co}(\mathrm{II}), \mathrm{Ni}(\mathrm{II}), \mathrm{Cu}(\mathrm{II})$, and $\mathrm{Na}(\mathrm{I})$, and of the $\mathrm{COOH}$ in 2-methoxyphenoxyacetic acid

\begin{tabular}{cccccc}
\hline $\begin{array}{c}\text { Complex } \\
\mathrm{L}=\mathrm{C}_{9} \mathrm{H}_{9} \mathrm{O}_{4}\end{array}$ & $v_{\mathrm{C}=\mathrm{O}}$ & $v_{\text {as OCO }}$ & $v_{\text {sym OCO }}$ & $\Delta v_{\text {OcO }}$ & $v_{\text {M-O }}$ \\
\hline $\mathrm{MnL}_{2} \cdot 4 \mathrm{H}_{2} \mathrm{O}$ & - & 1654 & 1425 & 229 & 465 \\
$\mathrm{CoL}_{2} \cdot 4 \mathrm{H}_{2} \mathrm{O}$ & - & 1619 & 1412 & 207 & 470 \\
$\mathrm{NiL}_{2} \cdot 4 \mathrm{H}_{2} \mathrm{O}$ & - & 1603 & 1414 & 189 & 472 \\
$\mathrm{CuL}_{2} \cdot 4 \mathrm{H}_{2} \mathrm{O}$ & - & 1597 & 1427 & 170 & 465 \\
$\mathrm{HL}$ & 1742 & - & - & - & - \\
$\mathrm{NaL}$ & - & 1615 & 1427 & 188 & 454 \\
\hline
\end{tabular}

The X-ray diffraction patterns of hydrated, intermediate and final products of complex thermal decompositions were taken on a HZG-4 (Carl Zeiss Jena) diffractometer using $\mathrm{Ni}$ filtered $\mathrm{Cu}$ $\mathrm{K} \alpha$ radiation. The measurements were made within the range $2 \Theta=4-80^{\circ}$ by means of the Bragg - Brentano method. The relationships between $\mathrm{I} / \mathrm{I}_{\mathrm{o}}$ and $2 \Theta$ for these complexes are presented in Fig.1. 

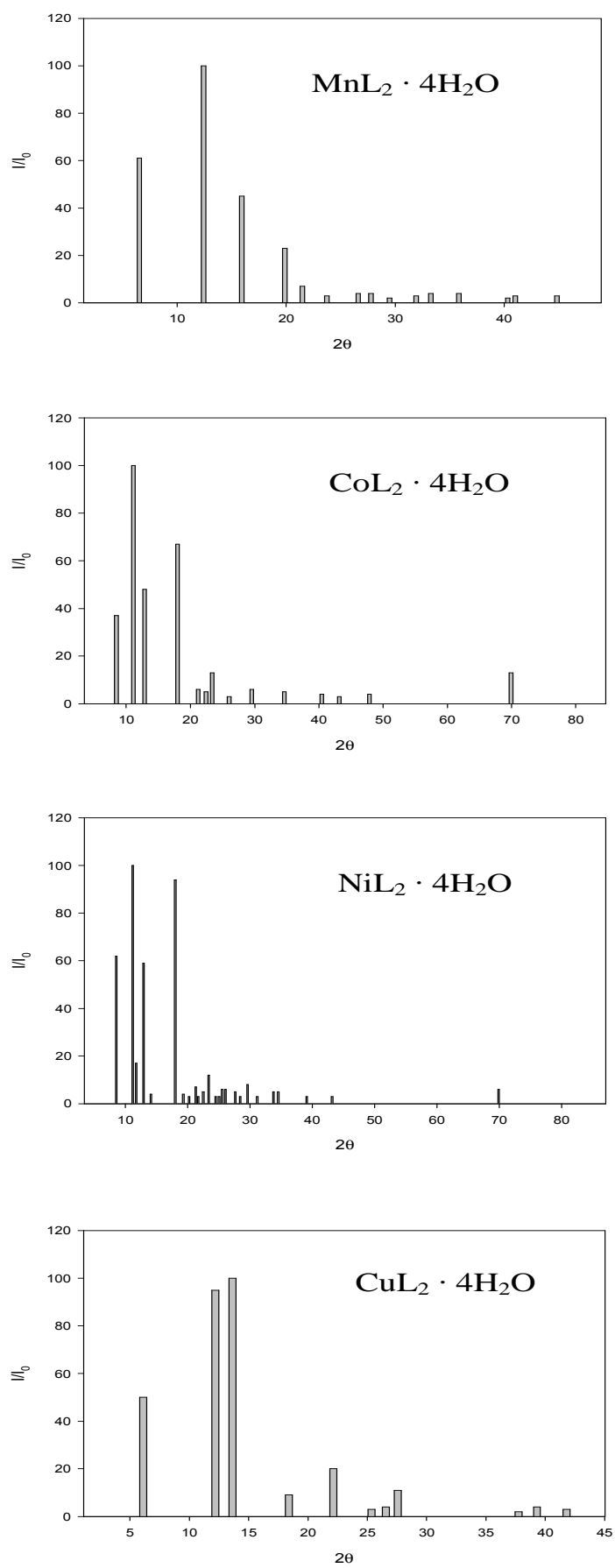

Fig.1. Dependence of $\mathrm{I} / \mathrm{I}_{0}$ vs $2 \theta$ for $\mathrm{Mn}(\mathrm{II}), \mathrm{Co}(\mathrm{II})$, $\mathrm{Ni}(\mathrm{II})$ and $\mathrm{Cu}$ (II) complexes

The thermal stability and decomposition of the analysed complexes were determined by Pau-
lik-Paulik-Erday Q-1500D derivatograph with Derill converter, recording TG, DTG, and DTA curvers (Fig.2). The measurements were made at a heating rate of $10 \mathrm{~K} \cdot \mathrm{min}^{-1}$ with a full scale. The samples $(100 \mathrm{mg})$ were heated in platinum crucibles in static air to $1273 \mathrm{~K}$ with a sensitivity of TG-100mg. DTG and DTA sensitivities were regulated by a Derill computer program. The products of decomposition were calculated from $\mathrm{TG}$ curves and verified by the diffraction pattern registration and IR spectra. The thermogravimetric analysis of DSC/TG was performed at temperature $323-723 \mathrm{~K}$ using a differential thermoanalyzer Netzsch STA 409C 3F. The measurements were carried out under nitrogen flow $(99,995 \%$ purity) and temperature increase rates of $1-12 \mathrm{~K} \cdot \mathrm{min}^{-1}$. 
Table 3. Temperature ranges of thermal stability of $\mathrm{Mn}(\mathrm{II}), \mathrm{Co}(\mathrm{II}), \mathrm{Ni}(\mathrm{II})$ and $\mathrm{Cu}(\mathrm{II})$ 2-methoxyphenoxyacetates in air

\begin{tabular}{ccccccccc}
\hline \multirow{2}{*}{$\begin{array}{c}\text { Complex } \\
\mathrm{L}^{-}=\mathrm{C}_{9} \mathrm{H}_{9} \mathrm{O}_{4}\end{array}$} & $\Delta \mathrm{T}_{1} / \mathrm{K}$ & \multicolumn{2}{c}{ Mass loss $/ \%$} & $\mathrm{n}$ & $\mathrm{H} / \mathrm{kJ} \cdot \mathrm{mol}^{-1}$ & $\begin{array}{c}\Delta H_{1 H_{2} \mathrm{O}} / \\
\mathrm{nJ} \cdot \mathrm{mol}^{-1}\end{array}$ & Residue \\
\hline $\mathrm{MnL}_{2} \cdot 4 \mathrm{H}_{2} \mathrm{O}$ & $348-443$ & 14,73 & 14,69 & 4 & 128,91 & 32,2 & $\mathrm{MnO}$ \\
$\mathrm{CoL}_{2} \cdot 4 \mathrm{H}_{2} \mathrm{O}$ & $353-433$ & 14,61 & 14,70 & 4 & 113,76 & 28,4 & $\mathrm{CoO}$ \\
$\mathrm{NiL}_{2} \cdot 4 \mathrm{H}_{2} \mathrm{O}$ & $323-433$ & 14,61 & 14,54 & 4 & 128,48 & 32,1 & $\mathrm{NiO}$ \\
$\mathrm{CuL}_{2} \cdot 4 \mathrm{H}_{2} \mathrm{O}$ & $318-393$ & 14,47 & 14,48 & 4 & 117,47 & 29,4 & $\mathrm{CuO}$ \\
\hline
\end{tabular}

$\Delta \mathrm{T}_{1}$ - temperature range of dehydration process, $\mathrm{n}$ - number of water molecules lost in the dehydration process, $\Delta \mathrm{H}$ - enthalpy of dehydration process, $\Delta H_{1 H_{2} \mathrm{O}}$ - enthalpy value for one molecule of water,

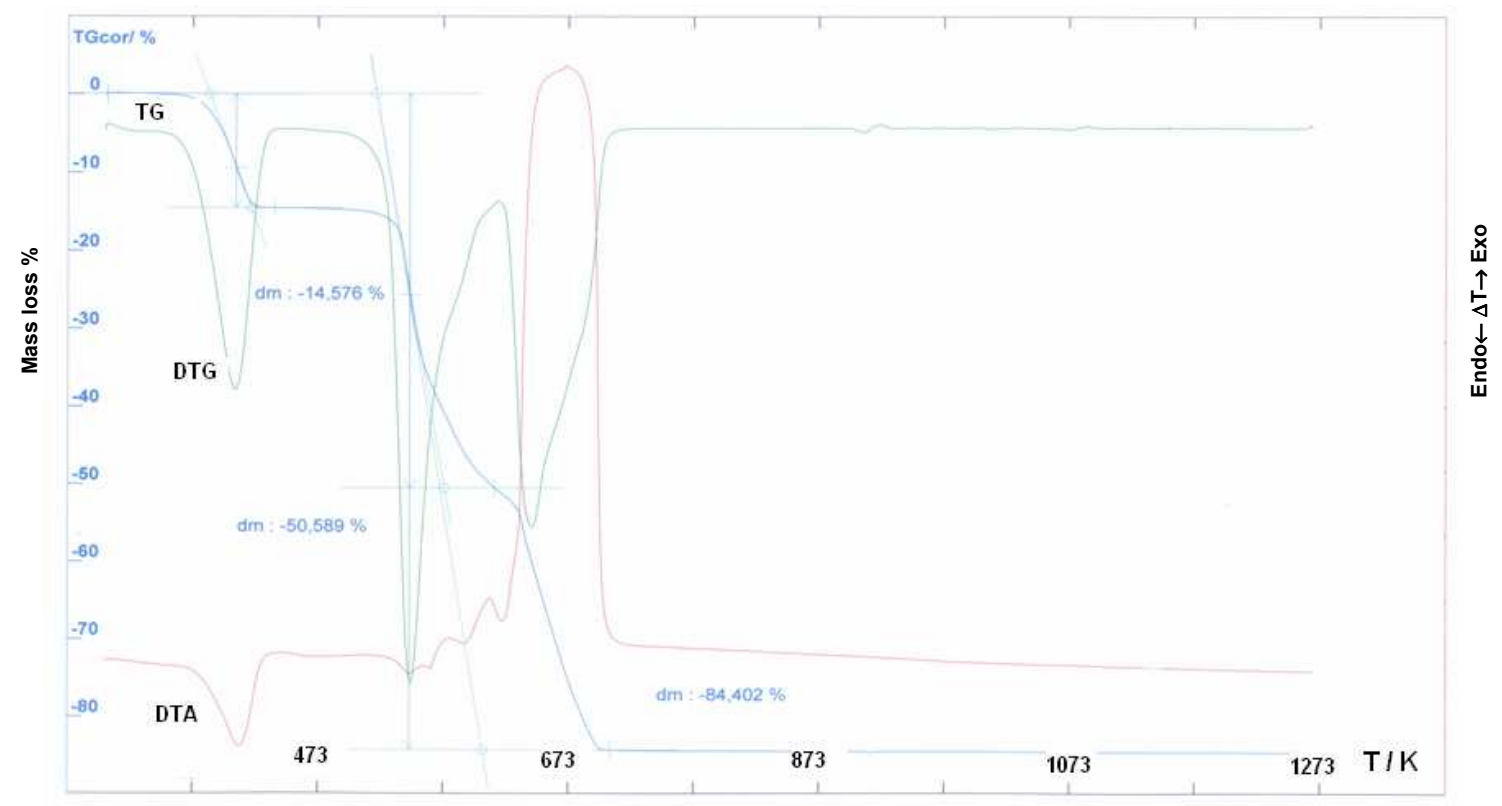

Fig.2. TG, DTG and DTA curves for Co(II) 2-methoxyphenoxyacetate

Magnetic susceptibilities of polycrystalline samples of 2-methoxyphenoxyacetates of $\mathrm{Mn}(\mathrm{II})$, $\mathrm{Co}(\mathrm{II}), \mathrm{Ni}(\mathrm{II})$ and $\mathrm{Cu}(\mathrm{II})$ were measured by the Gouy method using a sensitive Cahn RM-2 balance. The samples were placed in a long cylindrical tube which was suspended from an analytical balance. The sample tube was positioned between the poles of the magnet such that one its end was in the region of homogeneous field and the other end was in the region of zero field. The force exerted on the sample was a function of the volume occupied by the sample in the region of the field gradient. This force may be written in scalar form as a function of the isotropic volume susceptibility. Measurements were carried out at a magnetic field strength of 9,9 kOe. The calibrant employed was $\mathrm{Hg}\left[\mathrm{Co}(\mathrm{SCN})_{4}\right]$ for which the magnetic susceptibility was assumed to be $1,644 \cdot 10^{-5} \mathrm{~cm}^{3} \mathrm{~g}^{-1}$. 
Correction for diamagnetism of the calibrant atoms was calculated by the use of Pascal's constants $[8,9]$. Magnetic moments were calculated from Eq.(1):

$\mu_{\mathrm{eff}}=2,83\left(\chi_{\mathrm{M}} \cdot \mathrm{T}\right)^{1 / 2}$

Table 4. Magnetic data for the studied complexes of $\mathrm{Mn}(\mathrm{II}), \mathrm{Co}(\mathrm{II}), \mathrm{Ni}(\mathrm{II})$ and $\mathrm{Cu}(\mathrm{II})$

\begin{tabular}{|c|c|c|c|c|c|c|c|c|c|c|c|}
\hline \multicolumn{3}{|c|}{$\begin{array}{l}\mathrm{MnL}_{2} \cdot 4 \mathrm{H}_{2} \mathrm{O} \\
\mathrm{L}^{-}=\mathrm{C}_{9} \mathrm{H}_{9} \mathrm{O}_{4}\end{array}$} & \multicolumn{3}{|c|}{$\mathrm{CoL}_{2} \cdot 4 \mathrm{H}_{2} \mathrm{O}$} & \multicolumn{3}{|c|}{$\mathrm{NiL}_{2} \cdot 4 \mathrm{H}_{2} \mathrm{O}$} & \multicolumn{3}{|c|}{$\mathrm{CuL}_{2} \cdot 4 \mathrm{H}_{2} \mathrm{O}$} \\
\hline $\mathrm{T} / \mathrm{K}$ & $\chi_{M} \cdot 10^{6}$ & $\mu_{\mathrm{eff}} / \mu_{\mathrm{B}}$ & $\mathrm{T} / \mathrm{K}$ & $\chi_{M} \cdot 10^{6}$ & $\mu_{\mathrm{eff}} / \mu_{\mathrm{B}}$ & $\mathrm{T} / \mathrm{K}$ & $\chi_{M} \cdot 10^{6}$ & $\mu_{\mathrm{eff}} / \mu_{\mathrm{B}}$ & $\mathrm{T} / \mathrm{K}$ & $\chi_{M} \cdot 10^{6}$ & $\mu_{\mathrm{eff}} / \mu_{\mathrm{B}}$ \\
\hline 76 & 60395 & 6.06 & 76 & 31831 & 4.40 & 76 & 16750 & 3.19 & 76 & 5747 & 1.87 \\
\hline 123 & 38190 & 6.13 & 123 & 21090 & 4.56 & 123 & 10150 & 3.16 & 123 & 3483 & 1.85 \\
\hline 133 & 34155 & 6.03 & 133 & 19687 & 4.58 & 133 & 9434 & 3.17 & 133 & 3317 & 1.88 \\
\hline 143 & 31641 & 6.02 & 143 & 18628 & 4.62 & 143 & 8986 & 3.21 & 143 & 3059 & 1.87 \\
\hline 153 & 29635 & 6.03 & 153 & 17653 & 4.65 & 153 & 8461 & 3.22 & 153 & 2875 & 1.88 \\
\hline 163 & 27849 & 6.03 & 163 & 16344 & 4.62 & 163 & 7937 & 3.22 & 163 & 2709 & 1.88 \\
\hline 173 & 26371 & 6.04 & 173 & 15511 & 4.64 & 173 & 7489 & 3.22 & 173 & 2581 & 1.89 \\
\hline 183 & 24982 & 6.05 & 183 & 14774 & 4.65 & 183 & 7093 & 3.22 & 183 & 2433 & 1.89 \\
\hline 193 & 23880 & 6.08 & 193 & 14108 & 4.67 & 193 & 6747 & 3.23 & 193 & 2341 & 1.90 \\
\hline 203 & 22777 & 6.09 & 203 & 13454 & 4.68 & 203 & 6440 & 3.24 & 203 & 2212 & 1.90 \\
\hline 213 & 21796 & 6.10 & 213 & 12871 & 4.69 & 213 & 6108 & 3.23 & 213 & 2139 & 1.91 \\
\hline 223 & 20749 & 6.09 & 223 & 12216 & 4.67 & 223 & 5788 & 3.22 & 223 & 1991 & 1.89 \\
\hline 233 & 19889 & 6.09 & 233 & 11717 & 4.68 & 233 & 5532 & 3.21 & 233 & 1936 & 1.90 \\
\hline 243 & 19183 & 6.11 & 243 & 11348 & 4.70 & 243 & 5340 & 3.22 & 243 & 1863 & 1.90 \\
\hline 253 & 18522 & 6.13 & 253 & 10967 & 4.71 & 253 & 5148 & 3.23 & 253 & 1826 & 1.92 \\
\hline 263 & 17904 & 6.14 & 263 & 10634 & 4.73 & 263 & 4982 & 3.24 & 263 & 1789 & 1.94 \\
\hline 273 & 17639 & 6.15 & 273 & 10599 & 4.77 & 273 & 4918 & 3.25 & 273 & 1734 & 1.99 \\
\hline 283 & 16934 & 6.20 & 283 & 10230 & 4.77 & 283 & 4803 & 3.27 & 283 & 1697 & 1.94 \\
\hline 293 & 16449 & 6.21 & 293 & 9921 & 4.78 & 293 & 4649 & 3.27 & 293 & 1660 & 1.96 \\
\hline 303 & 15986 & 6.23 & 303 & 9516 & 4.81 & 303 & 4419 & 3.27 & 303 & 1586 & 1.96 \\
\hline
\end{tabular}




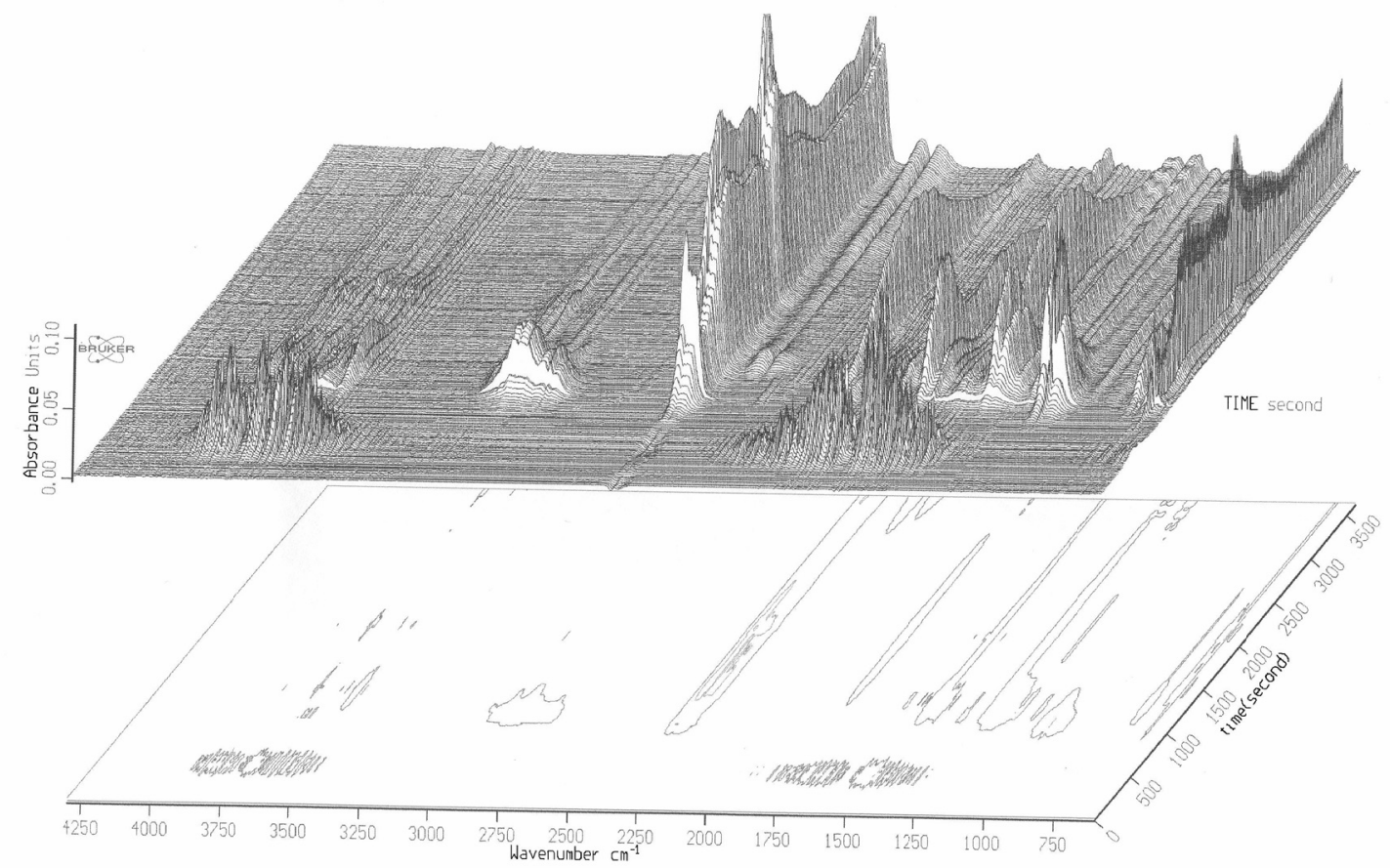

Fig.3. FTIR spectrum of gaseous products of thermal decomposition of Mn(II) 2-methoxyphenoxyacetate

The solubilities of 2-methoxyphenoxyacetates of $\mathrm{Mn}(\mathrm{II}), \mathrm{Co}(\mathrm{II}), \mathrm{Ni}(\mathrm{II})$ and $\mathrm{Cu}(\mathrm{II})$ in water were measured at 293K. Saturated solutions of the obtained compounds were prepared under isothermal conditions. The contents of $\mathrm{Mn}(\mathrm{II})$, $\mathrm{Co}(\mathrm{II}), \mathrm{Ni}(\mathrm{II})$ and $\mathrm{Cu}(\mathrm{II})$ were determined using ASA 880 spectrophotometer (Varian). The values of solubilities are presented in Table1.

\section{Results and Discussion}

2-Methoxyphenoxyacetates of $\mathrm{Mn}(\mathrm{II})$, $\mathrm{Co}(\mathrm{II}), \mathrm{Ni}(\mathrm{II})$ and $\mathrm{Cu}$ (II) were obtained as polycrystalline products with a metal ion to ligand ratio of $1: 2$ and the general formula $\mathrm{M}\left(\mathrm{C}_{9} \mathrm{H}_{9} \mathrm{O}_{4}\right)_{3} \cdot 4 \mathrm{H}_{2} \mathrm{O}$, where $\mathrm{M}(\mathrm{II})=\mathrm{Mn}, \mathrm{Co}, \mathrm{Ni}$ and $\mathrm{Cu}$. The colours of these complexes are typical for M(II) ions: pinkish for $\mathrm{Mn}(\mathrm{II})$, pink for $\mathrm{Co}(\mathrm{II})$, green for $\mathrm{Ni}(\mathrm{II})$, and blue for $\mathrm{Cu}$ (II). In these compounds the $\mathrm{d} \rightarrow \mathrm{d}$ electron transitions of the central ions are those of the lowest energy and absorption occurs at relatively high wave lengths that depends on the nature of the metal ion $[9,10]$.

The compounds were characterized by elemental analysis (Table 1), FTIR and FIR spectra (Table 2).

The 2-methoxyphenoxyacetates of Mn(II), $\mathrm{Co}(\mathrm{II}), \mathrm{Ni}(\mathrm{II})$ and $\mathrm{Cu}(\mathrm{II})$ exhibit similar solid state IR spectra. The band at $1742 \mathrm{~cm}^{-1}$ originating from the $-\mathrm{COOH}$ group, seen in the acid spectrum, is replaced in the spectra of complexes by two bands at $1619-1581 \mathrm{~cm}^{-1}$ and $1355-1341 \mathrm{~cm}^{-1}$, resulting from the asymmetric and symmetric vibrations of $\mathrm{COO}^{-}$group, respectively [11-14]. The bands with the maxima at $3565-3208 \mathrm{~cm}^{-1}, 1599-1505 \mathrm{~cm}^{-1}$ and $971-908 \mathrm{~cm}^{-1}$ confirm the presence of crystallization water molecules in the analyzed complexes. The bands of $v(\mathrm{C}=\mathrm{C})$ ring vibrations appear at $1654-1597 \mathrm{~cm}^{-1}, 1493 \mathrm{~cm}^{-1}, 1290-1010 \mathrm{~cm}^{-1}$ and $670-620 \mathrm{~cm}^{-1}$. The bands attributed to asymmetric and symmetric C-H stretching modes of the $\mathrm{CH}_{3}$ groups are observed at $2969-2928 \mathrm{~cm}^{-1}$ and $2924-$ $2901 \mathrm{~cm}^{-1}$, respectively. The bands of asymmetric and symmetric valency vibrations occur at 1260 1217 and $1060-1058 \mathrm{~cm}^{-1}$, respectively. The bands 
at $472-465 \mathrm{~cm}^{-1}$ confirm the ionic metal-oxygen bond [15-21]. In the range of $472-465 \mathrm{~cm}^{-1}$ they increase in the following way: $\mathrm{Mn}(\mathrm{II})=\mathrm{Cu}(\mathrm{II})<$ $\mathrm{Co}(\mathrm{II})<\mathrm{Ni}$ (II), which suggests the strongest $\mathrm{M}-\mathrm{O}$ bond in the case of $\mathrm{Ni}$ (II) complex.

The bands in the range of $336-276 \mathrm{~cm}^{-1}$ are connected with the $\mathrm{O}-\mathrm{H}$... O streching vibrations and they change their shapes according to the rise of atomic number of elements in 2-methoxyphenoxyacetates.

Table 2 presents the values of the two band frequencies of asymmetrical and symmetrical vibrations for carboxylate group of analyzed complexes. The separations of the $v_{\text {asCoO, }}$, and $v_{\mathrm{sCOO}}{ }^{-}$ modes in the compounds $\Delta v\left(\mathrm{COO}^{-}\right)$are greater or smaller than those of the sodium salt $\left(\Delta v_{\mathrm{COO}}{ }^{-}=\right.$ $\left.188 \mathrm{~cm}^{-1}\right)$ indicating a various degree of $\mathrm{M}-\mathrm{O}$ ionic bonds in 2-methoxyphenoxyacetates compared to that of the sodium salt. For the complexes the shifts of the frequencies of bands of $v_{\text {as }}\left(\mathrm{COO}^{-}\right)$, and $v_{\mathrm{s}}\left(\mathrm{COO}^{-}\right)$are lower and higher, respectively, than those for sodium 2-methoxyphenoxyacetate. Accordingly, taking into account the spectroscopic criteria $[12,14,22]$ the carboxylate ions appear to be monodentate (Co(II), $\mathrm{Ni}(\mathrm{II})$ and $\mathrm{Mn}(\mathrm{II})$ ) or bidentate $(\mathrm{Cu}$ (II) complex) groups.

In order to estimate the crystalline forms of the 2-methoxyphenoxyacetates the X-ray powder diffraction measurements were done. The diffractogram values suggest them to be polycrystalline compounds with various degree of crystallinity (Fig. 1) [23].

The thermal stability of $\mathrm{Mn}(\mathrm{II}), \mathrm{Co}(\mathrm{II})$, $\mathrm{Ni}(\mathrm{II})$, and $\mathrm{Cu}$ (II) 2-methoxyphenoxyacetates was studied in air at 293-1273 K (Table 3. Fig.2). When heated to $1273 \mathrm{~K}$ the $\mathrm{Mn}$ (II) complex is dehydrated in one step. In the temperature range of $348-443 \mathrm{~K}$ it losses two water molecules in one step and forms anhydrous salt. The loss of mass calculated from $\mathrm{TG}$ curve is equal to $14,69 \%$ (theoretical value is $14,73 \%$ ). The anhydrous salt at $603-703 \mathrm{~K}$ is gradually decomposed to $\mathrm{MnO}$ that is the final product of complex decomposition. The intermediate compound formed in this range of temperature is oxycarbonate of manganium. The dehydration process is connected with endothermic effect whereas the combustion of the organic ligand is accompanied by exothermic one. The final product of complex decomposition was confirmed by IR spectra and X-ray powder diffractogram.

The tetrahydrate of 2-methoxyphenoxyacetate of $\mathrm{Co}$ (II) during heating in air losses the water molecules in one step at $353-433 \mathrm{~K}$ and forms the anhydrous complex. The loss of mass calculated from TG curve is equal to $14,70 \%$ and calculated one $14,61 \%$. During heating the anhydrous salt $1183-1223 \mathrm{~K}$ is decomposed to $\mathrm{CoO}$ with the intermediate formation of oxycarbonate of cobalt. The final product of complex decomposition was identified by $\mathrm{X}$-ray powder diffractogram as $\mathrm{CoO}$. The dehydration process is accompanied with the endoeffect while that of oxidation by exothermic one (Fig.2).

When heated in air to $1273 \mathrm{~K}$ the tetrahydrate of $\mathrm{Ni}$ (II) 2-methoxyphenoxyacetate dehydrates in one step at $323-433 \mathrm{~K}$ and forms anhydrous complex. The found mass loss being equal to $14,54 \%$ corresponds to the loss of four molecules of water (theoretical value is equal to $14,61 \%)$. The anhydrous 2-methoxyphenoxyacetate of $\mathrm{Ni}$ (II) at $633-713 \mathrm{~K}$ is decomposed to $\mathrm{NiO}$, which is the final product of thermal decomposition. The dehydration process is connected with an endothermic effect seen in DTA curve, while the combustion of the organic ligand is connected with exothermic one.

During heating to $1273 \mathrm{~K}$ the $\mathrm{Cu}$ (II) complex dehydrates in one step. In the temperature range of 318 - $393 \mathrm{~K}$ it losses four molecules of water and forms anhydrous salt. The loss of mass calculated from TG curve is equal to $14,48 \%$ (the theoretical value is $14,47 \%$ ). The anhydrous complex at $598-768 \mathrm{~K}$ is decomposed to $\mathrm{CuO}$ that is a final product of complex decomposition. The intermediate compounds formed in this range of temperature may contain oxycarbonate of $\mathrm{Cu}, \mathrm{Cu}$ and $\mathrm{Cu}_{2} \mathrm{O}$ that being next oxidized to $\mathrm{CuO}$. The final product of complex decomposition was identified by X-ray powder diffractogram. The dehydration process, in this case, is connected with an endothermic effect seen on DTA curve, while the combustion of the organic ligand is accompanied by exothermic one. Considering the temperature of dehydration process and the way by which it proceeds it is possible to assume that the water molecules may be in the outer coordination sphere of the complex [24,25]. 
Taking into account the temperature values of the initial dehydration process it appears that $\mathrm{Co}$ (II) complex is the most thermally stable while $\mathrm{Cu}$ (II) compound has the least thermal stability because it starts to release water molecule at $318 \mathrm{~K}$.

The values of enthalpy of dehydration process were determined with the use of DSC/TG system under nitrogen atmosphere. They are in the range of $128,9-113,7 \mathrm{~kJ} \cdot \mathrm{mol}^{-1}$ and $32,2-28,4$ $\mathrm{kJ} \cdot \mathrm{mol}^{-1}$ per one molecule of water. These values indicate that the water molecule is the strongest bounded in the $\mathrm{Mn}$ (II) complex while that the weakest in Co(II) compound.

The decomposition process with the gas product analysis was recorded for 2-methoxyphenoxyacetates of $\mathrm{Mn}(\mathrm{II}), \mathrm{Co}(\mathrm{II}), \mathrm{Ni}(\mathrm{II})$ and $\mathrm{Cu}(\mathrm{II})$. For example the FTIR spectrum of gaseous products of decomposition process of $\mathrm{Mn}$ (II) 2-methoxyphenoxyacetate is presented in Fig.3. FTIR spectra of the gas phase products indicate that the decomposition of complexes is connected with the release of $\mathrm{CO}_{2}, \mathrm{CO}, \mathrm{H}_{2} \mathrm{O}$, alcohols and hydrocarbons. The characteristic valence and deformation vibration bands of water molecules in FTIR spectra appear in the wavenumber ranges of $4000-3500 \mathrm{~cm}^{-1}$ and $2000 \mathrm{~cm}^{-1}$. The bands characterictic for $\mathrm{CO}_{2}$ molecule vibrations occur in the following ranges: $2700-2500 \mathrm{~cm}^{-1}$ and 1000 $\mathrm{cm}^{-1}$. The bands of hydrocarbon vibrations are observed at $2250 \mathrm{~cm}^{-1-}$ and the band characteristic for CO molecule vibrations appears at $2060 \mathrm{~cm}^{-1}$. The bands typical for alcohol molecule vibrations are observed at $4000-3500 \mathrm{~cm}^{-1}$ and $1700-1500$ $\mathrm{cm}^{-1}$ [26-28].

The solubility of analyzed compounds was measured (Table 1). It is in the order of $10^{-5}$ $\mathrm{mol} \cdot \mathrm{dm}^{-3}$. The Co(II) 2-methoxyphenoxyacetate is the most soluble salt, while that of $\mathrm{Ni}$ (II) the least soluble one. The compounds are hardly soluble in water and the order value is not sufficient to use 2-methoxyphenoxyacetic acid for the separation of some metal ions by ion-exchange chromatography method.

The magnetic susceptibility of 2-methoxyphenoxyacetates of $\mathrm{Mn}(\mathrm{II}), \mathrm{Co}(\mathrm{II}), \mathrm{Ni}(\mathrm{II})$ and $\mathrm{Cu}$ (II) was measured in the temperature range of 77-303K (Table 4. Fig.4).

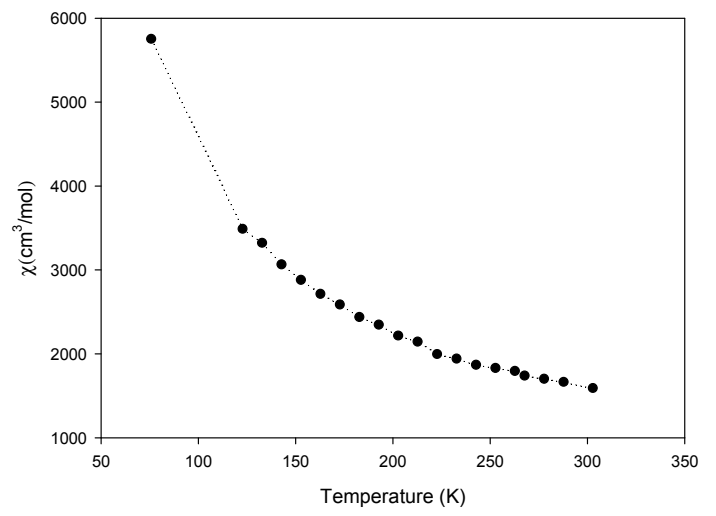

Fig.4. Dependence between magnetic susceptibility values vs temperatures for 2-methoxyphenoxyacetate of $\mathrm{Cu}(\mathrm{II})$

The values of the Weiss constant, $\Theta$, for all complexes were found to have a negative sign which probably arises from antiferromagnetic spin interaction or from a crystal field splitting of the paramagnetic spin state [29-34].

The magnetic moment values experimentally determined at $76-303 \mathrm{~K}$ for $\mathrm{Mn}(\mathrm{II}), \mathrm{Co}(\mathrm{II})$, $\mathrm{Ni}(\mathrm{II})$ and $\mathrm{Cu}(\mathrm{II})$ compounds change from $6,06 \mu_{\mathrm{B}}$ (at $76 \mathrm{~K}$ ) to $6,23 \mu_{\mathrm{B}}$ (at $303 \mathrm{~K}$ ) for $\mathrm{Mn}$ (II) complex, from $4,40 \mu_{\mathrm{B}}$ (at $76 \mathrm{~K}$ ) to $4.81 \mu_{\mathrm{B}}$ (at $303 \mathrm{~K}$ ) for $\mathrm{Co}(\mathrm{II})$, from $3,19 \mu_{\mathrm{B}}$ (at $76 \mathrm{~K}$ ) to $3.27 \mu_{\mathrm{B}}$ (at $303 \mathrm{~K}$ ) for $\mathrm{Ni}$ (II) and from $1.87 \mu_{\mathrm{B}}$ (at $76 \mathrm{~K}$ ) to $1,96 \mu_{\mathrm{B}}$ (at $303 \mathrm{~K}$ ) for $\mathrm{Cu}(\mathrm{II})$ 2-methoxyphenoxyacetates.

The magnetic moment data are very close to the spin only values for the respective ions calculated from the equation $\mu_{\text {eff }}=[4 s(s+1)]^{1 / 2}$ in the absence of the magnetic interactions for present spin-system. The magnetic moment values calculated at room temperature for $\mathrm{Mn}$ (II), $\mathrm{Co}(\mathrm{II})$, $\mathrm{Ni}(\mathrm{II})$ and $\mathrm{Cu}(\mathrm{II})$ ions are equal to $5,9 \mu_{\mathrm{B}}, 3,88$ $\mu_{\mathrm{B}}, 2,83 \mu_{\mathrm{B}}$, and $1,73 \mu_{\mathrm{B}}$, respectively. For $\mathrm{Mn}(\mathrm{II})$, $\mathrm{Co}(\mathrm{II}), \mathrm{Ni}(\mathrm{II})$ and $\mathrm{Cu}(\mathrm{II})$ ions the magnetic moment values may be different than the spin-only. These values are higher than the spin-only worth which results from a spin-orbital coupling. The experimental data suggest that these compounds are high-spin complexes with weak ligand field [29-34].

From the obtained results it appears that in 2-methoxyphenoxyacetates of $\mathrm{Mn}$ (II), $\mathrm{Co}$ (II), $\mathrm{Ni}(\mathrm{II})$ and $\mathrm{Cu}(\mathrm{II})$ the coordination numbers may 
be equal to 5 and 6 depending on the dentates of carboxylate group and the position of water molecules in the complex. The coordination numbers of $\mathrm{Mn}(\mathrm{II}), \mathrm{Co}(\mathrm{II}), \mathrm{Ni}(\mathrm{II})$ and $\mathrm{Cu}(\mathrm{II})$ ions could be established on the basis of the complete crystal structure determination of monocrystals but they have not been obtained so far.

\section{Conclusions}

On the basis of the results it appears that 2-methoxyphenoxyacetates of $\mathrm{Mn}$ (II), $\mathrm{Co}(\mathrm{II})$, $\mathrm{Ni}(\mathrm{II})$, and $\mathrm{Cu}$ (II) were synthesized as tetrahydrates. Their colours are typical for M(II) ions. The complexes are crystalline compounds and on heating in air to $1273 \mathrm{~K}$ they decompose in two steps: at first they dehydrate to form anhydrous compounds that next are decomposed to the oxides of respective metals. The values of $\mu_{B}$ calculated for analysed compounds reveal $\mathrm{Mn}$ (II), $\mathrm{Co}$ (II) and $\mathrm{Ni}$ (II) complexes to be high-spin and that of $\mathrm{Cu}$ (II) to be monomer.

\section{References}

[1] W. Ferenc, M. Bernat, J. Sarzyński, and B.Paszkowska, Ecl. Quim., São Paolo, 33 (1) (2008)7.

[2] S.C. Mojumdar, D. Hudecova and M. Melnik, Pol. J. Chem. 73 (1999)759

[3] M. McCann, J,F. Cronin and M. Devereux, Polyhedron, 17(1955)2379

[4] C.N. Rao, S. Natarajan, Angew, Chem. Int. Ed., 43(2004) 1446

[5] E.V. Dikarev, R.G. Gray, B. Li, Angew. Chem. Int. Ed., 44(2005) 1721

[6] J. Sokolik, I. Tumova, J. Valentova, E. Misikova, P. Svec, Act. Fac. Pharm. Univ. Com. T LIV (2007) 165-170

[7] B.N. Figgs, R.S. Nyholm, J. Chem. Soc. (1958) 4190

[8] E. König, Magnetic Properties of Coordination and Organometallic Transition Metal Compounds., Springer Verlag, Berlin. 1966

[9] A. Bartecki, Electronic Spectra of Complex Compounds, Scientific and Technical Publishers, Warsaw, 1987

[10] A.E. Orgel, An Introduction to Transition - Metal Chemistry, Ligand-Field Theory. John Wiley and Sons, New York, 1960

[11] L.J. Bellamy, The Infrared Spectra of Complex Molecules, Chapman L. Hall Ltd, London. 1975
[12] K. Nakamoto, Infrared and Raman Spectra of Inorganic and Coordination Compounds, John Wiley and Sons, Toronto, 1997

[13] A. Cross, A.R. Jones, An Introduction to Practical Infrared Spectroscopy. Butterworths, London, 1969

[14] R.C. Mehrotra, R. Bohra, Metal Carboxylates, Academic Press, London. 1983

[15] K. Burger, Coordination Chemistry: Experimental Methods, Akademiai Kiado, Budapest, 1973

[16] M. Mikami, I. Nakagawa, T. Simanouchi, Spectrochim. Acta, 23A (1967)1037

[17] Y. Kim, K. Machida, Spectrochim. Acta. 42A(1986)881

[18] K. Nakamoto, E. Udovich, J. Takemoto, J.Am. Chem. Soc., 92 (1970) 3973

[19] M.F. Richardson, W.F. Wagner, D.E. Sands, Inorg. Chem., 7(1968)2495

[20] A.K. Bridson, Inorganic Spectroscopic Metods, Oxford University Press, New York, 1988

[21] L.M. Harwood, T.D. Claridge, Introduction to Organic Spectroscopy, Oxford University Press, New York, 1999

[22] B.S. Manhas, A.K. Trikha, J. Indian. Chem. Soc. 59(1982) 315

[23] E. Łągiewka, Z. Bojarski, X-Ray Structural Analysis, Polish Sientific Publisher, Warsaw, 1988

[24] A.V. Nikolaev, A.V. Logvinienko, L.J. Myachina, L.J. Thermal Analysis Vol. 2. Academic Press, New York, 1989

[25] B. Singh, B.V. Agarwala, P.L. Mourya, A.K. Dey, J. Indian Chem. Soc. 59 (1992)1130

[26] L.A. Kazicyna, N.B. Kupletska, Spectroscopic Methods of the Structure Determination of Organic Compounds, PWN, Warsaw, 1976

[27] J.D. Roberts, M.C. Caserio, Organic Chemistry, PWN, Warsaw, 1969

[28] F. Paulik, Speciel Trends in Thermal Analysis, Wiley Chichester, 1995

[29] J. Mroziński, M. Janik, T. Nowakowski, Scientic Numbers of Silesian Technical University, 119(1988)125

[30] A. Earnshaw, Introduction to Magnetochemistry, Academic Press, London, 1956

[31] E. O'Connor, Progress in Inorganic Chemistry, Wiley, New York, 1982

[32] F.A. Kettle, Inorganic Physical Chemistry, Polish Scientific Publisher, Warsaw, 1999

[33] J. Mrozinski, Materials Science, Vol XIV (1988)3

[34] M. Hvastijova, M. Kochout, J. Mrozinski, J.Jäger, Polish J. Chem. $69(1995) 852$ 